\title{
ZAŠTITA POTROŠAČA U UGOVORIMA ZAKLJUČENIM VAN POSLOVNIH PROSTORIJA I UGOVORIMA ZAKLJUČENIM NA DALJINU U SAVREMENOM MEĐUNARODNOM PRIVATNOM PRAVU CRNE GORE
}

\begin{abstract}
Apstrakt: Zaštita potrošača jedan je od najvažnijih zadataka savremene Evropske unije. Iako je zaštita potrošača u Evropi započela pre više od pola vijeka, čini se da ova pitanja nikada nisu bila aktuelnija. Jedna od najvažnijih zaštita potrošača uspostavlja se na pitanjima međunarodne jurisdikcije i efikasne primjene mjerodavnog prava. Tema ovog rada je istražiti nivo ovog oblika zaštite potrošača prilikom zaključivanja ugovora van poslovnih prostorija i ugovora na daljinu u savremenom crnogorskom medunarodnom privatnom pravu, odnosno zaključivanja elektronskih ugovora sa međunarodnim elementom uopšte $i$ uticaja evropskog pravnog sistema na crnogorski pravni sistem. Ova pitanja su posebno relevantna u kontekstu sve veće upotrebe interneta u trgovini u Crnoj Gori.
\end{abstract}

Ključne riječi: $\quad$ potrošači, internet, zaštita, ugovori, Evropska unija, Crna Gora, mjerodavno pravo, međunarodna nadležnost.

\section{UVOD}

Međunarodno privatno pravo (u daljem tekstu i: MPP) kao grana prava svoje uporište u crnogorskim pravnim propisima nalazi još u XIX vijeku. Iako je tada Crna Gora bila značajno teritorijalno i demografski manja od ove sada, i bez posebno značajnog broja privatnopravnih situacija sa međunarodnim elementom, zahvaljujući širini svijesti i ogromnom pravničkom znanju Valtazara Bogišića, odredbe međunarodnog privatnog prava svoje mjesto su našle u Opštem imovinskom zakoniku za Knjaževinu Crnu Goru. ${ }^{1}$

Savremeno MPP je u Crnoj Gori kodifkovano Zakonom o međunarodnom privatnom pravu (Sl. list Crne Gore, br. 1/14, 6/14, 11/14, 14/14 i 47/15), koji je u primjeni od sredine 2014. godine. S obzirom na to da se ovim zakonom uređuju pravila za određivanje mjerodavnog prava u privatnopravnim odnosima sa međunarodnim elementom (kolizione norme), pravila o nadležnosti sudova i drugih

* Asistent na Fakultetu pravnih nauka Univerziteta Donja Gorica

e-mail: bojan.bozovic@udg.edu.me

1 Vid. opširnije: Babić, D., 2011, Međunarodno privatno pravo u Bogišićevom zakoniku, u: Bogišić i kultura sjećanja, Zbornik radova, Zagreb, str. 119-144. 
organa za raspravljanje tih odnosa i pravila postupka, kao i pravila za priznavanje i izvršenje stranih sudskih i arbitražnih odluka i odluka drugih organa, koja su u cjelosti ili u pretežnom dijelu usaglašena sa pravilima međunarodnog privatnog prava koje nastaje i razvija se u okrilju Evropske unije (u daljem tekstu: EU), a koje predstavlja acquis communautaire i neposredno i direktno obavezuje sve države članice EU, posebno je važno kontinuirano pratiti njegovu primjenu i, po potrebi, ukazivati na mjere i radnje koje je potrebno preduzimati u pravcu unaprjeđenja iste.

Prilikom pripreme novog zakona, bilo je neminovno da se nove tendencije na međunarodnom planu odraze i na Crnu Goru, pa novi zakon, u skladu sa članom 80. Sporazuma o stabilizaciji i pridruživanju između EU i Crne Gore, koji je stupio na snagu 1. maja 2010. godine, ide ka usklađivanju nacionalnog prava s pravom EU i u oblasti ugovornog prava. ${ }^{2}$

Polazeći od činjenice da će se, kada Crna Gora postane članica EU, sve uredbe $^{3}$ iz oblasti koje su predmet regulisanja međunarodnog privatnog prava neposredno primjenjivati i kod nas, smatralo se da je pri izradi novog zakona o međunarodnom privatnom pravu i odlučivanju o stepenu usaglašavanja njegovih odredaba s pravom EU cjelishodno imati diferenciran pristup prema vrsti materije koja je predmet evropske regulative, u zavisnosti od pretežnih nacionalnih interesa. Tako, u oblasti određivanja mjerodavnog prava za ugovorne i vanugovorne obaveze, recepcija pravila Uredbe br. 593/2008 o mjerodavnom pravu za ugovorne obaveze (Uredba Rim I) i Uredbe br. 864/2007 o mjerodavnom pravu za vanugovorne obaveze (Uredba Rim II), uz neophodna prilagođavanja, samo može biti u interesu Crne Gore, tim prije što je ovim uredbama predviđeno da imaju univerzalnu primjenu, pa se kao mjerodavno pravo u zemljama EU primjenjuje i na države koje nijesu članice Unije.

Organi primjene prava u Crnoj Gori su imali vremena da se upoznaju s praksom u primjeni ovih uredbi, a u zakonu stoji da će se tumačenje i primjena odredaba koje se odnose na ugovore, odnosno vanugovorne obaveze vršiti u skladu s uredbama Rim I i Rim II (čl. 49. i 67). ${ }^{4}$ I u oblasti međunarodne nadležnosti je došlo do značajnijih novina, u skladu sa novijim tendencijama u evropskom međunarodnom privatnom pravu, odnosno u skladu s rješenjima Uredbe Brisel, Uredbe Brisel I bis i Konvencije o nadležnosti i priznanju i izvršenju presuda u građanskim i trgovinskim stvarima iz Lugana, koja je revidirana 2007. godine. Naime, tradicionalno, opšta nadležnost suda Crne Gore određuje se prema prebivalištu, odnosno sjedištu tuženog u Crnoj Gori (actor sequitur forum rei) $)^{5}$. Ako tuženi nema prebivalište u Crnoj Gori niti u drugoj državi, nadležnost suda Crne Gore postoji ako tuženi ima boravište u Crnoj Gori (član 99). Takođe je od načelnog značaja zasnivanje, kao izuzetne, nadležnosti suda ili drugog organa u Crnoj Gori s kojim predmet ima dovoljnu vezu, ako se postupak ne može pokrenuti u inostranstvu ili se ne može razumno zahtijevati da tamo bude pokrenut (član 113). Ali ono što je za ovaj rad posebno značajno, došlo je

2 Kostić-Mandić, M., 2011, Osvrt na novo međunarodno privatno pravo u Crnoj Gori, Nova revija, 2, str. 71 .

3 Vid. npr. Uredbu Rim 1 gdje je u članu 1. stav 1 propisano da se uredba primjenjuje „u situacijama kada postoji sukob zakona, na ugovorne obveze u građanskim i trgovinskim stvarima”.

4 Kostić-Mandić, M., 2011, str. 73.

5 Ovaj princip je prihvaćen i u Uredbi Brisel I bis. 
do izmjena u okviru posebnih odredaba o nadležnosti na način da je po prvi put regulisana nadležnost za potrošačke ugovore (član 124).

\section{POTROŠAČ U SAVREMENOM SISTEMU ZAŠTITE U PRAVU EU I EVROPSKOM MPP-U SA POSEBNIM OSVRTOM NA ONLAJN TRGOVINU - NEDOSTACI ELEKTRONSKE TRGOVINE}

Zaštita slabije strane je kratka i jasna, naspram duge i kompleksne istorije nastanka i razvoja međunarodnog privatnog prava ${ }^{6}$. Od svog nastanka međunarodno privatno pravo, posebno sukob zakona, pokazalo je ravnodušnost prema materijalnopravnom konceptu zaštite slabije strane. ${ }^{7}$ Tek se putem prava EU sistemski, putem sofisticiranih pravila izgradio sveobuhvatni model zaštite potrošača. ${ }^{8}$ Pri tome je u pravu EU uzet u obzir razvoj kupovine putem interneta i specifičnih karakteristika tako zaključenih potrošačkih ugovora. ${ }^{9}$

Za razliku od SAD, u Evropi je zaštita potrošača postala i dio međunarodnog privatnog prava. Razvoj međunarodnog privatnog prava i zaštita potrošača bila je u tijesnoj vezi sa socijalnom politikom u Evropi toga doba, ali i zaštitom ljudskih prava koja se ogledala u zaštiti slabije strane. To je za posljedicu imalo snažan napredak u razvoju potrošačke politike tokom šezdesetih godina dvadesetog vijeka u Zapadnoj Evropi. Ova tendencija je izdvojila potrošačko pravo iz trgovinskog prava, a samim tim i međunarodno privatno pravo je moralo da kreira prava u skladu sa ovim novim subjektom.

Osnovni element za definisanje pojma potrošač leži u činjenici da je riječ o fizičkom licu, što je potvrđeno presudom Suda EU u vezanim predmetima Idealservice $^{10}$. U pomentom predmetu su sudije odlučile da pojam potrošač treba tumačiti u skladu sa pomenutom odredbom Direktive 93/13/EZ kojom su isključena pravna lica. Druga dva kriterijuma su da fizičko lice mora zaključiti ugovor koji se odnosi na pravni posao koji ne spada u okvir njegovog profesionalnog djelovanja, dok druga strana (trgovac) mora činiti suprotno.

\subsection{ZAŠTITA POTROŠAČA PRILIKOM ONLAJN TRGOVINE U EVROPSKIM PRAVNIM IZVORIMA}

U Evropskoj uniji potrošač se, raznim pravnim pravilima (direktivama, uredbama, odnosno regulativama, ali i primarnim izvorima) štiti kao slabija ugovorna strana, s obzirom na to da je politika Evropske unije oblast koju ova organizacija sistemski razvija već više decenija. Glavni instrument za harmonizaciju

6 Tang, Z. S., 2009, Electronic Consumer Contracts in the Conflict of Laws, Oxford and Portland, p. 4.

7 Ibid., p. 5.

$8 \quad$ Ibid.

9 Ibid

10 ECJ, Cape Snc v. Idealservice Srl (C-541/99) and Idealservice MN RE Sas v. OMAI Srl(C-542/99), Judgment of the Court (Third Chamber) of 22 November 2001. 
privatnog prava država članica jeste direktiva, iako zaštitu potrošačkih prava možemo naći i među primarnim ${ }^{11}$ izvorima. Važno je istaći i da Direktiva 93/13 EEZ ima prednost $\mathrm{u}$ odnosu na nacionalni propis, ali i na evropske propise. ${ }^{12}$ Direktiva je obavezujuća u pogledu svog cilja koji slijedi. Tako ona ostavlja nacionalnim zakonodavcima prostor da odaberu najpovoljniji oblik i metode implementacije direktive.

S druge strane, uredbe imaju opštu i direktnu primjenjivost. Posebne norme $\mathrm{u}$ korist potrošača $\mathrm{u}$ međunarodnom privatnom i procesnom pravu su prvenstveno osigurane kroz član 6. Uredbe Rim I i čl. 15-17. Uredbe Brisel I, odnosno čl. 17-19. Uredbe Brisel I bis. Mjerodavno pravo u slučajevima spora na osnovu odgovornosti za proizvod s nedostatkom određeno je Uredbom Rim II.

Uredbom Brisel I potrošač je definisan kao osoba koja sklapa ugovor „u svrhe koje se ne mogu smatrati njenom profesionalnom ili poslovnom djelatnošću“. Uredba Brisel I dakle prepoznaje potrošača kao osobu koja je zaključila ugovor izvan djelokruga svog zanimanja ili profesije. ${ }^{13}$ Identičnu definiciju nalazimo u Uredbi Rim I ${ }^{14}$. Prilikom tumačenja ovog pojma, uvijek treba imati na umu da ono mora biti autonomno i da se ne mogu na njega primjenjivati načela bilo kojeg unutrašnjeg nacionalnog prava. Međutim, u Uredbi Brisel I i Uredbi Rim I propisano je da pojmove vezane za potrošačke ugovore treba „usklađeno tumačiti“, iz čega možemo zaključiti da se, barem načelno, tumačenje pojma potrošač za svrhu primjene Uredbe Brisel I može primjenjivati i kod primjene Uredbe Rim I ${ }^{15}$.

Uredbom Brisel I izričito je određeno na koje se vrste ugovora odnose odredbe o nadležnosti, dakle, određeno je polje primjene. Tako je propisano da ugovor mora sklopiti potrošač, a mora se raditi o jednom od tri navedene kategorije ugovora: a) o ugovoru o kupoprodaji robe sa otplatom cijene na rate; b) o ugovoru o zajmu sa otplatom na rate ili o ugovoru o bilo kakvom drugom obliku kredita sklopljenim za finansiranje prodaje robe ili u svim drugim slučajevima; c) o ugovoru sklopljenom sa licem koje obavlja trgovačku ili profesionalnu djelatnost u državi članici u kojoj potrošač ima domicil, ili ako na bilo koji način usmjerava svoje djelatnosti u tu državu članicu ili više država uključujući tu državu članicu, a ugovor spada u okvir te djelatnosti ${ }^{16}$.

Prema članu 6. Uredbe Rim I, ugovor koji sklopi fizičko lice u svrhu za koju se smatra da je izvan njegove struke ili profesije (potrošač) sa drugom osobom

11 Iz perspektive potrošačkih interesa, projekat ekonomske integracije pojavio se u Ugovoru iz Mastrihta 1991. godine, koji uvodi posebno poglavlje XI (član 129 a), posvećeno zaštiti potrošača, čime se Zajednici daje pravo na preduzimanje mjera na tom području. Taj je sektor međutim potpuno oslobođen povezanosti sa zakonodavstvom zajedničkog tržišta tek Ugovorom iz Amsterdama iz 1996. godine.

12 Kunda, I., Ništetnost prorogacijske i arbitražne klauzule u potrošačkim ugovorima u praksi Suda EU, u: Tomljenović, V., Petrić, S., Miščenić, E. (ur.), 2013, Nepoštene ugovorne odredbe Europski standard i hrvatska provedba, Rijeka, Pravni fakultet Sveučilišta u Rijeci, str. 256.

13 Sajko, K., 2009, Medunarodno privatno pravo, Zagreb, str. 402.

14 Član 6. Uredbe Rim I - Regulation (EC) No 593/2008 of the European Parliament and of the Council of 17 June 2008 on the law applicable to contractual obligations (Rome I).

15 Uredba Rim I, recital 24.

16 Član 17. Uredbe Brisel I - Regulation (EU) No 1215/2012 of the European Parliament and of the Council of 12 December 2012 on jurisdiction and the recognition and enforcement of judgments in civil and commercial matters (Brussels I). 
koja djeluje u svojoj struci ili profesiji (preduzetnik) podliježe pravu države u kojoj potrošač ima uobičajeno boravište, pod uslovom da preduzetnik:

a) sprovodi svoje komercijalne ili stručne djelatnosti u državi u kojoj potrošač ima uobičajeno boravište ili

b) bilo kojim sredstvima usmjerava takve aktivnosti na tu državu ili na više država, uključujući tu državu, te da je ugovor obuhvaćen opsegom tih aktivnosti.

Kada je riječ o navedenim odredbama, jasno je da najveći značaj za onlajn potrošačke ugovore ima član 17(1)(c) (nekad 15(1)(c) Uredbe Brisel I) jer prethodno dvije navedene vrste imaju veoma malu mogućnost primjene u praksi.

Iako se često kao izvor međunarodnog privatnog prava pominje i Briselska konvencija, vrijedi pomenuti da je tekst člana 13. ovog ugovora ${ }^{17}$ izrađen prije razvoja interneta i porasta elektronske trgovine. Budući da je član 13. sastavljen u kontekstu stvarnog tadašnjeg svijeta, koristi pojmove koji se ne mogu direktno primijeniti na onlajn situacije. Kao rezultat toga, smatralo se da je primjena člana 13. u kontekstu elektronske trgovine bila neizvjesna. Što se tiče kriterijuma „marketinga“ člana 13. (koji zahtijeva od dobavljača da izvrši „posebnu pozivnicu“ naručiocu ili da se uključi u „oglašavanje“ u državi prebivališta potrošača), razumno je jasno da održavanje internet stranice (koja je dostupna s bilo kojeg mjesta u svijetu od strane bilo koga ko ima računar povezan s internetom) nije „specifična pozivnica“ upućena korisnicima. Nasuprot tome, ponuda izvršena elektronskom poštom je „specifičan poziv“, jer je usmjeren na pojedinca ${ }^{18}$. Što se tiče kriterijuma "ugovaranja“ iz člana 13. Briselske konvencije (koji zahtijeva od potrošača da preduzme „korake potrebne za sklapanje ugovora“ u državi članici prebivališta), u situacijama na mreži može biti teško tačno reći gdje je potrošač preduzeo relevantne korake.

Suština člana 15(1)(c) Uredbe Brisel I (danas člana 17) jeste u sljedećem: Budući da je bilo koja veb-lokacija gotovo uvijek dostupna u svim državama članicama EU, svaki vlasnik veb-mjesta koji ima prebivalište u državi članici EU može se tužiti u bilo kojoj državi članici EU, bez obzira na to da li želi ili ne da posluje u dotičnoj državi članici. ${ }^{19}$

Ipak, vrijedno je pomenuti da je Ugovorom o funkcionisanju Evropske unije zaštita potrošača uređena članom 169. kojim je predviđeno da države članice mogu uvoditi i strože kriterijume zaštite potrošača od onih koji su predviđeni komunitarnim pravom, što predstavlja jednu značajnu potvrdu i od strane primarnih izvora o neophodnosti zaštite potrošača u savremenom svijetu.

Ali zašto se smatralo da je usklađivanje komunitarnih, evropskih pravila neophodno? Postoje dva ključna argumenta. Prvi koji se generalno koristi da bi opravdao potrebu za usklađivanjem: kad se zaključi ugovor (domaći ili preko-

17 Pravila o sudskoj nadležnosti u međunarodnim ugovorima u Evropskoj uniji su prvi put unifikovana u Briselskoj konvenciji o sudskoj nadležnosti i izvršenju sudskih odluka u građanskim i trgovinskim predmetima potpisanoj 27. septembra 1968. godine. 
granični/transnacionalni), on će biti podložan jednom pravnom propisu. Naime čim transakcija više nije domaća (čim imamo elemenat inostranosti, prekograničnosti), najmanje dva prava (prava potrošača i prava trgovca) nadmeću se kao međusobno suprotstavljena prava sa međunarodno-privatnopravnim elementom koji se primjenjuje na tu transakciju. Stoga je potrebno odrediti (izborom strana ili drugim pravilima) zakon koji će „upravljati“ tom transakcijom, pri čemu je izbor uglavnom između zakona nadležnosti trgovca, odnosno potrošača. Sukob interesa, $s$ jedne strane onlajn trgovca, a $s$ druge samih potrošača, rezultirao je oprečnim rješenjima zavisno od toga čijim je interesima zakonodavac dao prioritet. Pristup države porijekla koji pridaje značenje djelatnostima prodavca kao vlasnika internet stranice prihvaćen je $\mathrm{u}$ američkom pravu, ${ }^{20}$ dok je u evropsko pravo uveden princip dostupnosti informacije, odnosno princip države odredišta. ${ }^{21}$

Komplikovaniji faktor je činjenica da potrošači nisu dovoljno sigurni da će biti adekvatno zaštićeni kada kupuju robu ili traže usluge u inostranstvu, naročito kada govorimo o sistemu kolektivne zaštite.

Harmonizovani zakoni stoga proizvode sigurnije potrošače i više prekograničnih transakcija u korist unutrašnjeg tržišta. Nisu svi uvjereni u ovu argumentaciju, posebno zato što drugi faktori praktičnije vrste (na primer, jezik i prevoz) odmah objašnjavaju nevoljnost potrošača da kupuju u inostranstvu - ali se ti faktori ne mogu tako lako riješiti zakonodavstvenom intervencijom. Uostalom da ovi problemi i danas postoje, potvrđuje i nedavna presuda Suda pravde Evropske unije u postupku Verein für Konsumenteninformation v. Amazon EU $S_{a ̀ r} l^{22}$. U pomenutom slučaju Verein für Konsumenteninformation (Udruženje za informisanje potrošača, u daljem tekstu i: VKI), udruženje potrošača sa sjedištem u Austriji, pred austrijskim je sudovima podnijelo zahtjev za pokretanje postupka za dobijanje sudskog naloga, kojim zahtijeva da se Amazonu EU Sàrl sa sjedištem u Luksemburgu zabrani da u svojim opštim uslovima u odnosu na potrošače s prebivalištem u Austriji koristi navodno nepoštene odredbe. $U$ tom pogledu Oberster Gerichtshof (Vrhovni sud, Austrija) najprije pita Sud pravde Evropske unije koje je pravo mjerodavno u okviru takvog postupka pri ispitivanju nepoštene prirode takvih odredaba. Treba li ga odrediti na osnovu pravila o sukobu zakona iz Uredbe Rim II, s obzirom na to da je cilj udruženja koje je tužilac zaštititi skupne interese potrošača na osnovu ovlašćenja koja su mu zakonom dodijeljena, nezavisno od konkretnog ugovornog odnosa? Ili mjerodavno pravo treba odrediti na osnovu pravila o sukobu zakona iz Uredbe Rim I, s obzirom na to da moguća povreda skupnih interesa potrošača proizlazi iz ugovornih odnosa između njih i tuženog preduzetnika? Sud koji je uputio zahtjev nadalje je želio znati je li odredba u ugovoru sklopljenom u okviru elektronske trgovine kojom se kao mjerodavno pravo određuje pravo države članice u kojoj preduzetnik ima sjedište nepoštena na temelju Direktive 93/13/EEZ. Konačno, sud koji je uputio zahtjev želi saznati u skladu s kojim nacionalnim pravom kojim se pre-

20 Ibid., pp. 134-135.

21 Ibid.

22 ECLI:EU:C:2016:612, predmet C-191/15, Verein für Konsumenteninformation v. Amazon EU Sàrl, presuda od 28. jula 2016. 
nosi Direktiva 95/46/EZ treba ocijeniti zakonitost ugovornih odredaba kojima se predviđa obrada ličnih podataka od strane preduzetnika u elektronskoj trgovini kao što je Amazon EU, koji svoje djelatnosti usmjerava na državu članicu koja nije država članica u kojoj ima svoje sjedište.

$\mathrm{Na}$ konkretna pitanja, prvo je Sudu mišljenja iznio nezavisni pravobranilac Henrik Saugmandsgaarda Øea. ${ }^{23}$ Pravo koje se, po njegovom mišjenju, primjenjuje na ispitivanje nepoštene prirode odredaba u opštim uslovima preduzetnika koje su namijenjene potrošačima s prebivalištem u drugoj državi članici treba odrediti na osnovu člana 6. stava 1. Uredbe Rim II ako se ispitivanje sprovodi u okviru postupka za dobijanje sudskog naloga koji je pokrenut na osnovu nacionalnog zakona kojim je prenesena Direktiva 2009/22/EZ Evropskog parlamenta i Savjeta od 23. aprila 2009. o sudskim nalozima za zaštitu interesa potrošača te čiji je cilj zabrana korišćenja tih odredaba. S druge strane, član 4. stav 3. Uredbe br. 864/2007 nije relevantan za određivanje prava koje se primjenjuje na ispitivanje nepoštene prirode odredaba u opštim uslovima preduzetnika koje su namijenjene potrošačima s prebivalištem u drugoj državi članici ako se ispitivanje sprovodi u okviru postupka za dobijanje sudskog naloga koji je pokrenut na temelju nacionalnog zakona kojim je prenesena Direktiva 2009/22/EZ te čiji je cilj zabrana korišćenja tih odredaba. Takođe, nezavisni pravobranilac je bio mišljenja da član 3. stav 1. Direktive 93/13/EEZ o nepoštenim uslovima u potrošačkim ugovorima treba tumačiti na način da je odredba sadržana u opštim uslovima preduzetnika o kojoj se nije pojedinačno pregovaralo, u skladu s kojom ugovor sklopljen $s$ potrošačem u elektronskoj trgovini podliježe pravu države članice sjedišta preduzetnika, nepoštena ako zbog nje potrošač može steći pogrešan utisak da se na ugovor primjenjuje samo pravo te države članice, a da ga se njome ne informiše da na temelju člana $6 a$, stav 2 . Uredbe Rim I ima i pravo pozvati se na zaštitu koja mu se osigurava obaveznim odredbama prava koje bi se primjenjivalo bez te odredbe. Na nacionalnom je sudu da to ispita s obzirom na sve relevantne okolnosti slučaja. I u krajnjem, član 4. stav 1. tačku (a) Direktive 95/46/ EZ Evropskog parlamenta i Savjeta od 24. oktobra 1995. o zaštiti pojedinaca u vezi s obradom ličnih podataka i o slobodnom protoku takvih podataka treba tumačiti na način da postupak obrade ličnih podataka može podleći samo pravu jedne države članice. Pritom je riječ o državi članici u kojoj nadzornik obrade ima poslovno sjedište, na način da ondje putem stabilnih aranžmana obavlja efektivnu i stvarnu djelatnost, u smislu čijih se aktivnosti sprovodi predmetna obrada podataka. Na nacionalnom je sudu da to ocijeni.

$\mathrm{Na}$ pomenuto Mišljenje, a uzimajući u obzir relevatno pravo, Sud pravde Evropske unije je prihvatio gotovo svu argumentaciju pravobranioca i donio presudu u skladu sa njegovim mišljenjem. ${ }^{24}$

23 Vid. tačku 129. Mišljenja.

24 Sud u tački 82 zaključuje: 1.) Uredbu (EU) br. 593/2008 Evropskog parlamenta i Savjeta, od 17. juna 2008, o pravu koje se primjenjuje na ugovorne obaveze (Rim I) i Uredbu (EU) br. 864/2007 Evropskog parlamenta i Savjeta, od 11. jula 2007, o pravu koje se primjenjuje na vanugovorne obaveze („Rim II”), treba tumačiti na način da, ne dovodeći u pitanje član 1 . stav 3. svake od tih uredbi, pravo primjenjivo na postupak za dobijanje sudskog naloga, u smislu Direktive 2009/22/EZ Evropskog parlamenta i Savjeta od 23. aprila 2009. o sudskim 
Sud Evropske unije je, kao i u predmetu Oceano Grupo ${ }^{25}$, naglasio kako je cilj Direktive 93/13/EEZ (ali, rekli bismo, i svih izvora o zaštiti potrošačkih prava) postići da nepoštene ugovorne odredbe ne obavezuju potrošače. Zaštita koju uživaju potrošači temelji se na činjenici da oni predstavljaju slabiju stranu u poslovnom odnosu i svako postupanje koje onemogućava sudove da utiču na uspostavljanje ravnoteže između potrošača i pružaoca usluga bilo bi protivno njenoj svrsi, a elemenat inostranosti ili način zaključenja ugovora, u konkretnom slučaju ugovora na daljinu, apsolutno ne može biti razlog za nedovoljnu i neadekvatnu zaštitu potrošača.

Dosadašnje iskustvo sa pravnom tekovinom Evropske unije u pogledu zaštite potrošača pokazuje da praksa usaglašavanja nacionalnih zakona ne mora nužno stvoriti bolji pravni okvir za potrošačke transakcije na unutrašnjem tržištu. Iako su nacionalni zakoni postali suštinski usaglašeniji, postoje i dalje problemi tačne i jednake primjene. Ključna pitanja ostaju isključivo za nacionalno zakonodavstvo, kao što su dostupnost štete i određivanje onoga što se može povratiti.

\section{ZAŠTITA POTROŠAČA U PRAVU CRNE GORE I U CRNOGORSKOM MPP-u}

$\mathrm{Na}$ isključivo praktičnom nivou za nas, ako bi došlo do spora između potrošača i trgovca sa prekograničnim elementima, još uvijek bi bilo potrebno utvrditi pravo koje se primjenjuje na ugovor - i nacionalni zakon koji se primjenjuje i specifične pravne odredbe nacionalnog prava koje bi bile relevantne. Dakle, u konačnom, poznavanje nacionalnih zakona i dalje je relevantno za rješavanje prekograničnih sporova. S tim u vezi, važno je pomenuti kako su pitanja zaštite potrošača

nalozima za zaštitu interesa potrošača, usmjereno protiv korišćenja navodno nezakonitih ugovornih odredbi od strane preduzetnika s poslovnim nastanom u državi članici koja sklapa ugovore elektronskim putem s potrošačima koji su rezidenti u drugim državama članicama, a osobito u državi u kojoj se nalazi sud pred kojim se vodi postupak, treba odrediti u skladu s članom 6. stavom 1. Uredbe br. 864/2007, dok pravo koje je mjerodavno za ocjenu date ugovorne odredbe treba uvijek odrediti primjenom Uredbe br. 593/2008, bilo da se ta ocjena izvrši u okviru individualne tužbe ili kolektivne tužbe. 2.) Član 3. stav 1. Direktive Savjeta 93/13/EEZ, od 5. aprila 1993. o nepoštenim uslovima u potrošačkim ugovorima, treba tumačiti na način da je odredba koja se nalazi među opštim uslovima prodaje prodavca (robe) ili pružaoca (usluge), koja nije bila predmet individualnih pregovora, prema kojoj je ugovor sklopljen u okviru elektronske trgovine s potrošačem uređen pravom države članice sjedišta tog prodavca (robe) ili pružaoca (usluge), nepoštena ako dovodi tog potrošača u zabludu dajući mu dojam da se samo pravo te države primjenjuje na ugovor, a da ga ne obavještava o činjenici da na temelju člana 6. stava 2. Uredbe br. 593/2008 uživa zaštitu koju mu osiguravaju obavezne odredbe prava koje bi bilo mjerodavno u nedostatku te odredbe, što je na nacionalnom sudu da utvrdi s obzirom na sve relevantne okolnosti. 3.) Član 4. stav 1. tačku (a) Direktive 95/46/EZ Evropskog parlamenta i Savjeta, od 24. oktobra 1995. o zaštiti pojedinaca u vezi s obradom ličnih podataka i o slobodnom protoku takvih podataka, treba tumačiti na način da je obrada osobnih podataka koju izvrši preduzetnik za e-trgovinu uređena pravom države članice prema kojoj taj preduzetnik usmjerava svoje aktivnosti ako se pokaže da taj preduzetnik predmetne podatke obrađuje u okviru aktivnosti poslovnog sjedišta smještenog u toj državi članici. Na nacionalnom je sudu da ocijeni je li to slučaj.

25 Sud Evropske unije, presuda Suda od 27. juna 2000. u predmetu Océano Grupo Editorial SA v. Roció Murciano Quintero (C-240/98). 
po ovom pitanju regulisana u Crnoj Gori, naročito Zakonom o zaštiti potrošača. Potrošač je, u smislu ovog zakona, fizičko lice koje zaključuje pravni posao ili djeluje na tržištu van svoje trgovinske, poslovne, zanatske ili profesionalne djelatnosti. ${ }^{26}$ Trgovac je, u smislu ovog zakona, lice koje, samostalno ili preko drugog lica koje nastupa u njegovo ime ili za njegov račun, zaključuje pravni posao ili djeluje na tržištu u okviru svoje trgovinske, poslovne, zanatske ili profesionalne djelatnosti. ${ }^{27}$ Ipak, zakonodavac podsjeća i na hijerarhijski odnos izvora prava, pa ističe da se odredbe Zakona o zaštiti potrošača primjenjuju na odnose između potrošača i trgovca, osim ako je posebnim zakonom, koji je usklađen sa pravnom tekovinom Evropske unije, drugačije propisano. ${ }^{28} \mathrm{Na}$ obligacione odnose između potrošača i trgovca primjenjuju se odredbe zakona kojim se uređuju obligacioni odnosi, ako ovim zakonom nije drukčije uređeno. ${ }^{29} \mathrm{U}$ skladu sa relevantnim izvorima EU MPP-a, ovaj unutrašnji pravni izvor propisuje da izborom stranog prava kao mjerodavnog, potrošač koji ima boravište u Crnoj Gori ne može biti lišen zaštite na koju ima pravo u skladu sa ovim zakonom. ${ }^{30}$

Osim toga, poredeći sa trenutnim pravnim okvirom evropskog međunarodnog privatnog prava, iz ugla potrebe potrošača za zaštitom nije odgovarajuće da je takva zaštita dostupna protiv preduzetnika iz EU, a da primjena prinudnih propisa EU sadržanih u brojnim direktivama postane neizvjesna, jer se Uredba Brisel I ne primjenjuje na potrošačke sporove u kojima je tuženi trgovac sa sjedištem van EU. ${ }^{31}$ Prema novoj formulaciji člana 18. stav 1. Brisela I, forum actoris potrošača vrijedi bez obzira na to da li je sjedište druge ugovorne strane $u$ EU ili ne, dok je član 6. stav 1. Brisela I forum actoris iz člana 18. stav 1. Brisela I naveden kao jedan od izuzetaka od uslova sjedišta tuženog u EU za primjenu Uredbe Brisel I. Ekonomske posljedice ovakve regulacije mogu biti pozamašne, jer se preduzeća koja nemaju sjedište ili poslovnicu u EU više ne mogu izvući od nadležnosti uređene prema Uredbi Brisel I. ${ }^{32}$

Član 70. Ustava Crne Gore (Sl. list Crne Gore, br. 1/07) propisuje obavezu zaštite potrošača. Odredbom je predviđena i obaveza države da štiti od aktivnosti koje štete zdravlju, bezbjednosti i privatnosti potrošača. Dakle, našim najvišim pravnim aktom je ustanovljena ustavna obaveza državnih organa, čime je zaštita potrošača prepoznata kao posebna politika u pravnom sistemu Crne Gore, čime se preuzima princip zasnovan u primarnim izvorima Evropske unije.

Zakonom o zaštiti potrošača ${ }^{33}$ uređuje se zaštita prava potrošača pri kupovini i drugim oblicima prometa proizvoda na tržištu, a naročito: zaštita ekonomskih interesa, pravna zaštita, informisanje i obrazovanje, udruživanje potrošača radi zaštite njihovih interesa i druga pitanja od značaja za zaštitu potrošača.

26 Član 2. stav 1. Zakona o zaštiti potrošača.

27 Član 2. stav 1. Zakona o zaštiti potrošača.

28 Član 3. stav 1. Zakona o zaštiti potrošača.

29 Član 3. stav 2. Zakona o zaštiti potrošača.

30 Član 5. stav 1. Zakona o zaštiti potrošača.

31 Magnus, U., Mankowski, P., 2014, Brussels I Regulation, Munich, European Law Publisher, p. 626.

32 Ibid.

33 Zakon o zaštiti potrošača, Sl. list Crne Gore, br. 2/14, 6/14, 43/15, 70/17, 67/19. 
Ugovor zaključen na daljinu je ugovor zaključen između trgovca i potrošača u okviru organizovanog sistema prodaje ili pružanja usluge bez istovremenog fizičkog prisustva trgovca i potrošača na istom mjestu, pri čemu se do trenutka zaključenja ugovora i za zaključenje ugovora isključivo koristi jedno ili više sredstava komunikacije na daljinu. ${ }^{34}$

Ugovor zaključen van poslovnih prostorija je ugovor između trgovca i potrošača koji je zaključen: 1) uz istovremeno fizičko prisustvo trgovca i potrošača na istom mjestu koje ne predstavlja poslovne prostorije trgovca, i u slučaju kada je potrošač dao ponudu; 2) u poslovnim prostorijama trgovca ili putem sredstava komunikacije na daljinu neposredno nakon što je trgovac pristupio potrošaču lično na mjestu van poslovnih prostorija; 3 ) za vrijeme izleta koji je organizovao trgovac s namjerom ili ciljem promocije ili prodaje robe ili usluga potrošaču. ${ }^{35}$

U Crnoj Gori, sporazum kojim se potrošač i trgovac obavezuju da će spor rješavati pred određenim tijelom za rješavanje sporova ne obavezuje potrošača ako je zaključen prije nastanka spora i ako se na osnovu tog sporazuma potrošač odriče prava na sudsku zaštitu u parničnom postupku. ${ }^{36}$ Ako tijela za rješavanje sporova primjenjuju postupak čiji je ishod obavezujuća odluka, ta odluka može biti obavezujuća za stranke samo ako su stranke tu posljedicu izričito prihvatile. ${ }^{37}$ Ako pak tijelo za rješavanje sporova primjenjuje postupak čiji je ishod obavezujuća odluka, treba da obezbijedi da: 1) u situaciji u kojoj nema sukoba zakona, obavezujuća odluka ne može za posljedicu da ima lišenje potrošača zaštite koja mu je zagarantovana odredbama od kojih se ne može odstupiti sporazumom, koje su na snazi u državi u kojoj potrošač i trgovac imaju svoje uobičajeno boravište ili sjedište; 2) u situaciji u kojoj postoji sukob zakona, obavezujuća odluka ne može za posljedicu da ima lišenje potrošača zaštite koja mu je zagarantovana odredbama od kojih se ne može odstupiti sporazumom, koje su na snazi u državi u kojoj potrošač ima uobičajeno boravište; 3 ) u situaciji u kojoj postoji sukob zakona, kada je mjerodavno pravo utvrđeno u skladu sa članom 5. st. 1. do 3. Rimske konvencije od 19. juna 1980. godine ${ }^{38}$ o mjerodavnom pravu za ugovorne obaveze, obavezujuća odluka ne može za posljedicu da ima lišenje potrošača zaštite koja mu je zagarantovana prinudnim propisima države u kojoj potrošač ima uobičajeno boravište. ${ }^{39}$ Protiv obavezujuće odluke, koja ima snagu pravosnažne presude i koja je izvršna, može se podnijeti tužba za poništaj pred sudom. Stranke se ne mogu unaprijed odreći prava da zahtijevaju poništenje odluke. ${ }^{40}$ Ako utvrdi da je tužbeni zahtjev osnovan, sud će poništiti odluku i, u zavisnosti od razloga za poništaj, predmet može vratiti tijelu za rješavanje sporova na ponovni postupak. Na postupak po tužbi za poništaj odluke shodno se

34 Član 61. stav 1. Zakona o zaštiti potrošača.

35 Član 62. stav 2. Zakona o zaštiti potrošača.

36 Član 132j, stav 1. Zakona o zaštiti potrošača.

37 Član $132 j$, stav 2. Zakona o zaštiti potrošača.

38 Cijenimo da bi u narednim izmjenama ovog zakona trebalo da dođe i do usklađivanja sa Uredbom Rim I.

39 Član 132j, stav 3. Zakona o zaštiti potrošača.

40 Član $132 \mathrm{j}$, stav 5 . Zakona o zaštiti potrošača. 
primjenjuju odredbe o pobijanju arbitražnih odluka u skladu sa zakonom kojim se uređuje arbitraža.

Kada je o Zakonu o međunarodnom privatnom pravu riječ, on je, kao što smo naveli, u potpunosti prihvatio principe koji su propisani relevantnim izvorima EUMPP-a. Iz tog razloga je na našim organima da prate presude Suda pravde EU jer, kao što smo mogli vidjeti u prethodnom slučaju, još uvijek postoje određene praznine, nejasnoće i dileme u pogledu zaštite potrošača. Takođe, Crna Gora mora nastaviti proces harmonizacije koja mora biti podržana prije svega održivim i dobro osmišljenim rješenjima i ne bi smjela dovesti do pravne fragmentacije izazvane evropskim direktivama pravnim izvorima.

Članom 49. Zakona o međunarodnom privatnom pravu je izričito predviđeno da se tumačenje i primjena odredaba koje se odnose na ugovorne obaveze vrši u skladu sa Uredbom Rim I, što znači da su naši organi primjene već sada dužni da neposredno primjenjuju pravne tekovine Evropske unije u oblasti mjerodavnog prava za sve vrste ugovornih odnosa, pa i onih koji su predmet ovog rada. ${ }^{41}$ Odredbe o mjerodavnom pravu naročito se primjenjuju na: tumačenje ugovora; ispunjenja obaveza koje nastaju iz ugovora; posljedice potpunog ili djelimičnog ispunjenja, uključujući i visinu naknade štete koja je propisana, a u okviru ovlašćenja koja sud ima, prema procesnom pravu države suda; različite načine prestanka obaveza; zastarjelost; posljedice ništavosti ugovora ${ }^{42} \mathrm{Na}$ osnovu ovog pravnog propisa, za najveći broj ugovora primjenjivaće se pravilo o autonomiji volje stranaka, ${ }^{43}$ odnosno ako ugovorne strane nijesu izabrale mjerodavno pravo, koliziono pravilo o primjeni uobičajenog boravišta dužnika karakteristične obaveze, a u krajnjem slučaju primijeniće se princip najbliže veze. ${ }^{44}$ Izuzetak od ovih pravila predstavljaće norme o zaštiti potrošača koje su propisane članom 42. Zakona o međunarodnom privatnom pravu. Naime, pomenutom odredbom se u potpunosti preuzima član 6 . Uredbe Rim I, osim određenja pojma potrošača i trgovca. Izuzeci navedeni u stavovima 4. ova dva izvora ipak nijesu identični. Naime, za razliku od Uredbe Rim I koja u članu 6. predviđa pet vrsta izuzetaka od primjene prava uobičajenog boravišta potrošača, Zakon o međunarodnom privatnom pravu odnosi se na tri vrste ugovora: 1) ugovore o pružanju usluga, ako se te usluge pružaju potrošaču isključivo u državi koja nije država njegovog uobičajenog boravišta; 2) ugovore o prevozu, osim na ugovore kojima se za jedinstvenu cijenu pruža kombinovana usluga putovanja i smještaja; 3) ugovore čiji je predmet stvarno pravo na nepokretnosti ili zakup nepokretnosti, osim ugovora o pravu na vremenski ograničenu upotrebu nepokretnosti (timesharing) ${ }^{45}$ Kao što vidimo i kao što je poznato, poveznica autonomije volje

41 Kostić-Mandić, M., 2017, Međunarodno privatno pravo, Podgorica, str. 313.

42 Ibid.

43 Član 38. Zakona o međunarodnom privatnom pravu, Sl. list Crne Gore, br. 1/14, 6/14, 11/14, $14 / 14,47 / 15$.

44 Član 39. Zakona o međunarodnom privatnom pravu.

45 Član 6. stav 4. Uredbe Rim I je naveo sljedeće vrste ugovora: (a) ugovor za pružanje usluga kad je usluge potrebno pružiti potrošaču isključivo u državi koja nije država u kojoj ima uobičajeno boravište; (b) ugovor o prevozu koji ne predstavlja ugovor o paket-putovanju u smislu Direktive Savjeta 90/314/EEZ o paket-putovanjima, organizovanim izletima i paket-aran- 
stranaka ima znatno sužen značaj kod potrošačkih ugovora. Ugovorne strane, kao što vidimo, u crnogorskom pravu mogu izabrati neko drugo mjerodavno pravo (umjesto prava uobičajenog boravišta), ali se takvim izborom ne može uskratiti zaštita potrošaču po prinudnim propisima prava njegovog uobičajenog boravišta. Ovo se posebno odnosi na zaštitu potrošača prilikom elektronske trgovine kada ova ugovorna strana, zbog svega prethodno navedenog, može biti $\mathrm{u}$ naročito nepovoljnoj situaciji. Zato je u oblasti elektronske trgovine, Nacionalnim programom planiran rad na edukaciji crnogorskih potrošača o značaju i karakteru on-line trgovine, kao i mogućnostima potpune primjene svih oblika onlajn trgovine u realnom životu potrošača, kako bi na taj način oni osjetili koristi od elektronske trgovine. $U$ tom smislu, važno je i informisanje poslovnog sektora o novim obavezama u elektronskoj trgovini, a potrošačima pružiti informacije o bezbjednoj onlajn kupovini. Ovo uključuje informacije o indikatorima za prepoznavanje pouzdanog trgovca, odnosno prevare, sigurne metode plaćanja i bezbjednosna pravila koja se moraju poštovati. ${ }^{46}$

\section{UMJESTO ZAKLJUČKA}

U ovom radu izvršen je kratak osvrt na nastanak i razvoj savremenog međunarodnog privatnog prava Crne Gore, kao i tendencije koje su uticale na njegov postojeći oblik u pogledu zaštite potrošačkih prava u onlajn trgovini. Danas kada Crna Gora ima sve više privatnopravnih sporova sa međunarodnim elementom pred svojim sudovima, neophodnost izučavanja ove pravne discipline je veća nego ikada. Naime, prema podacima pribavljenim od Vrhovnog suda Crne Gore, osnovni sudovi su samo u periodu jul 2018 - jul 2019. godine primjenili odredbe Zakona o međunarodnom privatnom pravu u 495 predmeta, od čega 76 predmeta na oblast obligacionog prava. ${ }^{47}$ Kada se uporede podaci o ukupnom broju predmeta u kojima su u osnovnim sudovima u izvještajnom periodu primjenjene odredbe Zakona o međunarodnom privatnom pravu sa podacima iz prethodnog izvještajnog perioda (jul 2017 - jul 2018. godine), dolazi se do zaključka da su u izvještajnom periodu u znatno većem broju predmeta primjenjene odredbe navedenog zakona. Naime, osnovni sudovi su u izvještajnom periodu primjenili odredbe Zakona o međunarodnom privatnom pravu u 495 predmeta, dok je taj broj u prethodnom periodu iznosio 218 predmeta, što je

žmanima; (c) ugovor koji se odnosi na stvarno pravo nad nekretninama odnosno na pravo najma nekretnina, a koji ne predstavlja ugovor o pravu na vremenski ograničenu upotrebu nekretnine, u smislu Direktive 94/47/EZ; (d) prava i obaveze koji predstavljaju finansijski instrument, te prava i obaveze koji predstavljaju odredbe i uslove kojima podliježe izdavanje odnosno javna ponuda i javno preuzimanje ponuda prenosivih vrijednosnih papira, te unos i otkup jedinica u organizacijama za kolektivno ulaganje, u mjeri u kojoj te aktivnosti ne predstavljaju pružanje finansijskih usluga; (e) ugovor sklopljen unutar one vrste sistema koji je obuhvaćen članom 4. stavom 1. tačkom (h).

46 Vlada Crne Gore, Nacionalni program zaštite potrošača, 2015. godina, str. 24.

47 Izvještaj o primjeni Zakona o međunarodnom privatnom pravu u periodu od jula 2018. godine do jula 2019. godine, Podgorica, 2019, str. 4. 
za 277 predmeta ili 127,06\% više u odnosu na prethodni period. Kada je u pitanju oblast obligacionog prava, može se konstatovati da je ukupan broj predmeta $\mathrm{u}$ kojima su primjenjene odredbe Zakona o međunarodnom privatnom pravu u izvještajnom periodu povećan za 56 predmeta ili $280 \%$ u odnosu na prethodni period, jer broj navedenih predmeta u izvještajnom periodu iznosi 76 , dok je taj broj u prethodnom periodu iznosio 20 predmeta. Ali i pored toga, broj predmeta u pogledu zaštite potrošačkih ugovora i ugovora zaključenih elektronskim putem su rijetkost. To upućuje samo na potrebu izrade što više akademskih studija koje će se baviti ovom problematikom u Crnoj Gori, a naročito na neophodnost dosljedne primjene Zakona o zaštiti potrošača, ali i Zakona o MPP-u, a naročito praksi Suda Evropske unije koji treba da bude primjer domaćim sudovima u primjeni pomenutih izvora kako bi rad naših pravosudnih i ostalih organa bio što efikasniji i pravičniji.

\section{LITERATURA}

1. Babić, D., 2011, Međunarodno privatno pravo u Bogišićevom zakoniku, u: Bogišić i kultura sjećanja, Zbornik radova, Zagreb.

2. Bouček, V., 2009, Europsko međunarodno privatno pravo u eurointegracijskom procesu $i$ harmonizacija međunarodnog privatnog prava, Zagreb, vlastito izdanje.

3. Hill, J., 2008, Cross-border Consumer Contracts, Oxford.

4. Kostić-Mandić, M., 2017, Međunarodno privatno pravo, Podgorica.

5. Kostić-Mandić, M., 2011, Osvrt na novo međunarodno privatno pravo u Crnoj Gori, Nova revija, 2.

6. Kropholer, J. Von Hein, 2011, Europaischës Zivilprozessrecht, Hamburg.

7. Kunda, I., Ništetnost prorogacijske i arbitražne klauzule u potrošačkim ugovorima u praksi Suda EU, u: Tomljenović, V., Petrić, S., Miščenić, E. (eds.), 2013, Nepoštene ugovorne odredbe - Europski standard $i$ hrvatska provedba, Pravni fakultet Sveučilišta u Rijeci, Rijeka.

8. Magnus, U., Mankowski, P., 2012, Brussels I Regulation, Munich, European Law Publisher.

9. Sajko, K., 2009, Medunarodno privatno pravo, Zagreb.

10. Tang, Z. S., 2009, Electronic Consumer Contracts in the Conflict of Laws, Oxford and Portland.

\section{PROPISI}

1. Zakon o zaštiti potrošača, Sl. list Crne Gore, br. 2/14, 6/14, 43/15, 70/17, 67/19.

2. Zakon o međunarodnom privatnom pravu, Sl. list Crne Gore, br. 1/14, 6/14, 11/14, 14/14, 47/15.

3. Regulation (EC) No 593/2008 of the European Parliament and of the Council of 17 June 2008 on the law applicable to contractual obligations (Rome I).

4. Regulation (EU) No 1215/2012 of the European Parliament and of the Council of 12 December 2012 on jurisdiction and the recognition and enforcement of judgments in civil and commercial matters (Brussels I). 


\title{
SUDSKA PRAKSA
}

1. ECJ, Cape Snc v. Idealservice Srl (C-541/99) and Idealservice MN RE Sas v. OMAI Srl (C-542/99), Judgment of the Court (Third Chamber) of 22 November 2001.

2. ECJ, Océano Grupo Editorial SA v. Roció Murciano Quintero (C-240/98), Judgment of the Court of 27 June 2000.

3. ECLI:EU:C:2016:612, predmet C 191/15, Verein für Konsumenteninformation vs. protiv Amazon EU Sàrl presuda od 28. jula 2016.

\section{OSTALI IZVORI}

1. Vlada Crne Gore, Nacionalni program zaštite potrošača, 2015. godina.

2. Izvještaj o primjeni Zakona o međunarodnom privatnom pravu u periodu od jula 2018. godine do jula 2019. godine, Podgorica, 2019.

\section{CONSUMER PROTECTION CONCLUDING OFF-PREMISES AND DISTANCE CONTRACTS IN CONTEMPORARY MONTENEGRIN PRIVATE INTERNATIONAL LAW}

\author{
Bojan Božović \\ SUMMARY
}

Consumer protection is one of the most important tasks of the modern European Union. Although consumer protection in Europe has taken its toll half a century ago, it seems that these issues have never been more topical. One of the most important consumer protections is established through the establishment of international jurisdiction and effective applicable law.

The topic of this paper is to investigate the level of this form of consumer protection when concluding off-premises and distance contracts in contemporary Montenegrin private international law, or concluding online contracts with an international element in general and the influence of European legal system on Montenegrin legal system. These issues are particularly relevant in the context of the increasing use of the Internet in commerce in Montenegro.

Key words: consumers, Internet, protection, contracts, European Union, Montenegro, jurisdiction. 